\title{
HOW REALLY EXTENSIVE IS THE ORIGINAL MATERIAL OF JUNCUS KOCHII (JUNCACEAE)? - A TAXONOMIC AND NOMENCLATURAL REVISION
}

\author{
JAROSŁAW PROĆKÓW \\ Department of Biodiversity and Plant Cover Protection \\ Institute of Plant Biology, Wrocław University \\ Kanonia 6/8, 50-328 Wrocław, Poland \\ e-mail: jprockow@biol.uni.wroc.pl \\ (Received: October 5, 2007. Accepted: April 10, 2008)
}

\begin{abstract}
The identity of the original material of Juncus kochii F. W. Schultz (Juncaceae) is discussed. The taxon at present is best regarded as Juncus bulbosus L. subsp. kochii (F. W. Schultz) Reichg. The relevant literature (protologue and references therein) was searched and details of all original elements were compiled. Nomenclatural and taxonomic remarks are given. Juncus welwitschii Hochst. ex Steud. is here excluded as a synonym of Juncus bulbosus subsp. kochii.
\end{abstract}

KEY WORDS: bulbous rush, Juncaceae, Juncus bulbosus, Juncus bulbosus subsp. kochii, Juncus kochii, Juncus welwitschii, nomenclature, original material, typification.

\section{INTRODUCTION}

The paper forms a part of the 'Juncus bulbosus Synonyms Typification Project' (e.g., Proćków 2002, 2006a-c, 2007, 2008a, b), aimed at clarifying the complicated nomenclature (synonymy) within this extremely variable taxon (because of the high morphological diversity of the bulbous rush, there exist about 60 synonyms). Juncus kochii $\mathrm{F}$. W. Schultz and J. supinus Moench var. nigritellus W. D. J. Koch were lectotypified recently as homotypic (Proćków 2006a). At present they are best regarded as Juncus bulbosus L. subsp. kochii (F. W. Schultz) Reichg. (see e.g., Casper and Krausch 1980; Proćków 2006a).

It should be noted that Juncus kochii was treated as a substitute for "J. nigritellus W. D. J. Koch non D. Don" but Koch (1837) clearly cited Don without the intention of publishing a new name (Kirschner 2002). In this situation there was no evidence for the existence of the name $J$. nigritellus W. D. J. Koch (1837) non D. Don. Moreover, Schultz also (1855) did not mention in the J. kochii protologue Koch's validly published illegitimate junior homonym - J. supinus var. nigritellus W. D. J. Koch, 1844 nom. illeg. [non (D. Don) F. W. Schultz, 1840] but only his own misapplication of Don's epithet at varietal rank (i.e. a new combination based on D. Don's name $[=J$. supinus var. nigritellus (D. Don in J. E. Smith, 1831) F. W. Schultz, 1840
$=J$. supinus var. nigritellus $(\mathrm{D}$. Don ex Macreight, 1837) F. W. Schultz, $1840=$ synonym of $J$. articulatus L. subsp. articulatus], though erroneously applied to Koch's taxon cf. Art. 7.4 of the ICBN and see Proćków 2006a, b, 2007). Consequently, Art. 7.3 (Greuter et al. 2000) did not apply and only Schultz's own material was relevant for typification (Proćków 2006a).

The discussion on the original Schultz's material of $J$. kochii is introduced here because: (1) there were many controversies connected with the material earlier (i.e. which specimens are or are not the types), and (2) these significant data had been not included within my recent papers (Proćków 2006a,b). Thus the relevant literature (protologue and references therein) was searched and details of all original elements were compiled. Namely a few localities/collections are mentioned in the protologue of $J$. $\mathrm{ko}$ chii, and these specimens can, therefore, be regarded as original material (italic: after Schultz's indirect reference to his "Fl. d. Pfalz", 1846):

(a) nur in den kältesten Gegenden an den nördlichen Abdachungen der Wasserscheide des Vogesensandsteingebirgs und zwar am Ursprunge der nach Westen (der Blies, Saar und Mosel zu) fliessenden Bäche;

(b) an einem sumpfigen Waldabhange zwischen dem Stüderhofe und dem Dorfe Mölschbach, 2 Stunden 
von Kaiserslautern (seit Koch) zwischen Sphagnum und Hypnum oft mit Lysimachia nemorum, Blechnum spicant, Osmunda regalis;

(c) und am Fusse dieser hohen waldigen, nach Norden gerichteten Bergabhänge auf einer moosigen Moorwiese!;

(d) so wie eine Stunde weiter in den waldigen Bergthälern hinter Trippstadt, beim Lauberhof und beim Johanniskreuz.

The localities (and, consequently, also the original material) are thus more numerous than reported by Kirschner (2002: 162) - he cites only 'zwischen d. Stüderhofe u.d. Dorfe Mölschbach 2 Stunden v. Kaiserslautern' (Proćków 2006a).

Schultz (1855) cites, besides, the following references to earlier publications:

1) 'J. nigritellus Koch [1837] non Don', where only one locality is given: "In sylvarum mont [u]osarum locis uliginosis, (an einem sumpfigen Waldabhange zwischen $\mathrm{d}$. Stüderhofe u. d. Dorfe Mölschbach 2 Stunden v. Kaiserslautern v. mir selbst, aber mit unreifen Kapseln, gefunden)";

2) 'J. supinus $\delta$ nigritellus F. S. in Flora bot. Zeit. 1840, p. 640', with the locality "im Torfmoore zu Bitsch" (but see Proćków 2006b);

3) 'Fl. d. Pfalz' [Schultz 1846], where, compared to Schultz's later paper (1855) only after Blies stream, rivers Saar and Mosel are added (see above point a), and additional epithets for the locality for point c ("am Fusse dieser hohen waldigen, nach Norden gerichteten Bergabhänge auf einer moosigen Moorwiese!"). Furthermore, other, additional references are given here ('F. S. Arch. de la Fl. pag. 62', 'Fl. G. et G. exs., add. au 56 de la 4' Cent.', 'Juncus nigritellus Koch, F. S. Fl. G. et G. exs. 356 [it should be: 'exs. 56' - see Proćków 2006b]'), while the remaining ones are repeated as in other bibliographic positions cited by Schultz.

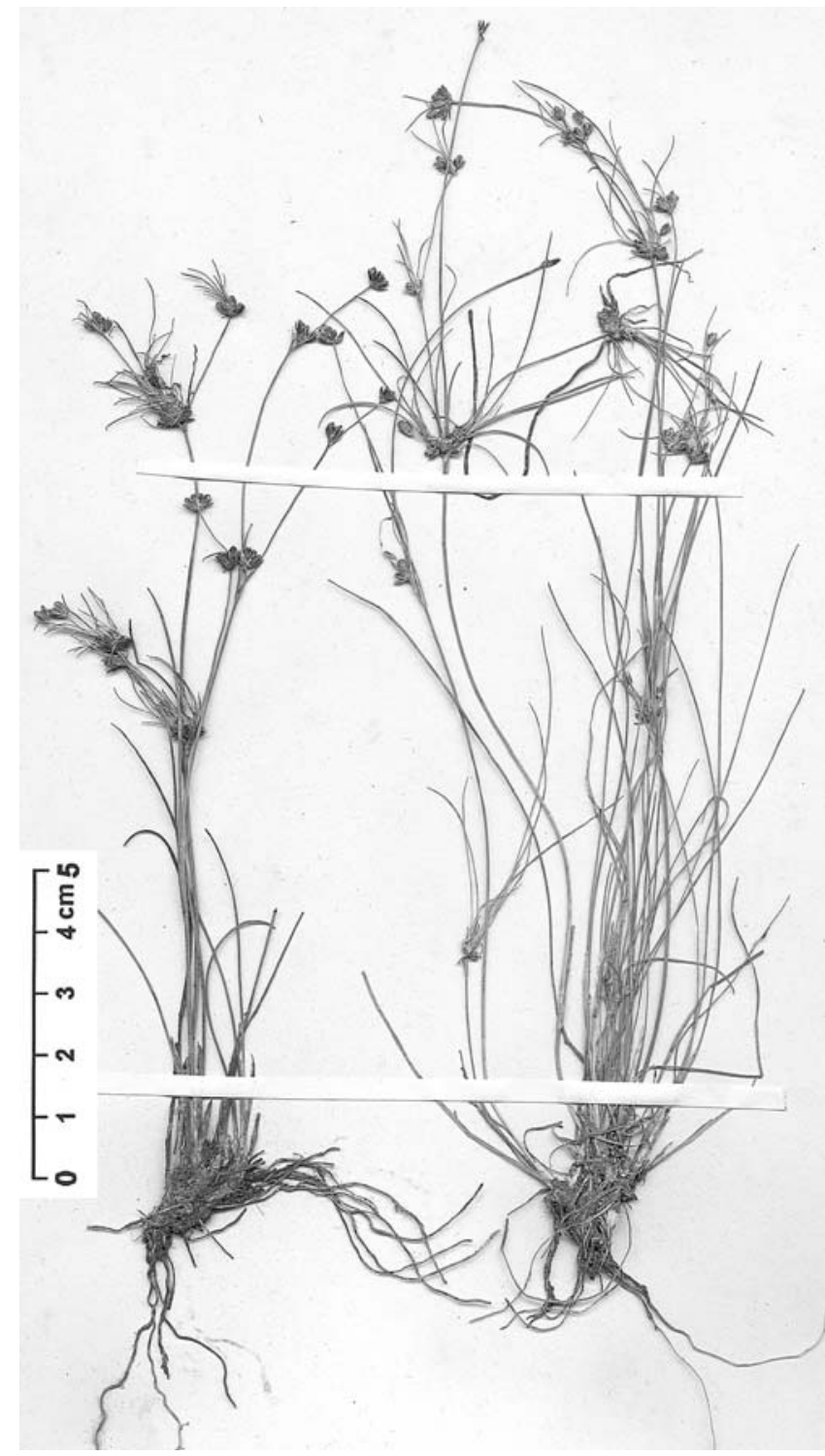

Fig. 1A. Original material of Juncus kochii gathered by F. W. Schultz near Mölschbach (Germany) in 1843 - plants from the herbarium sheet L 106430 ex Herb. W. D. J. Koch! (photo by the author).

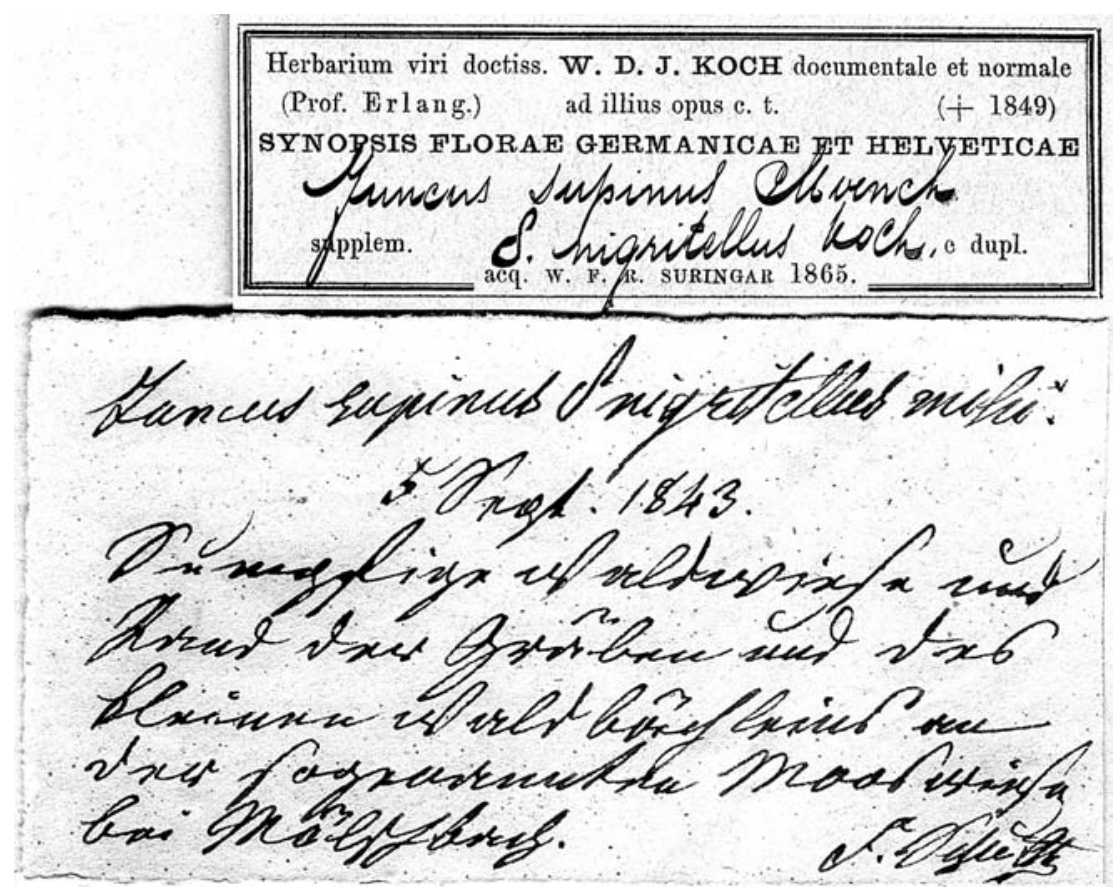

Fig. 1B. Schultz's gothic handwriting label (in German) and W. D. J. Koch's herbarium printed label - both from the herbarium sheet, which was subsequently acquired by W. F. R. Suringar in 1865 (L 106430! - photo by the author). 


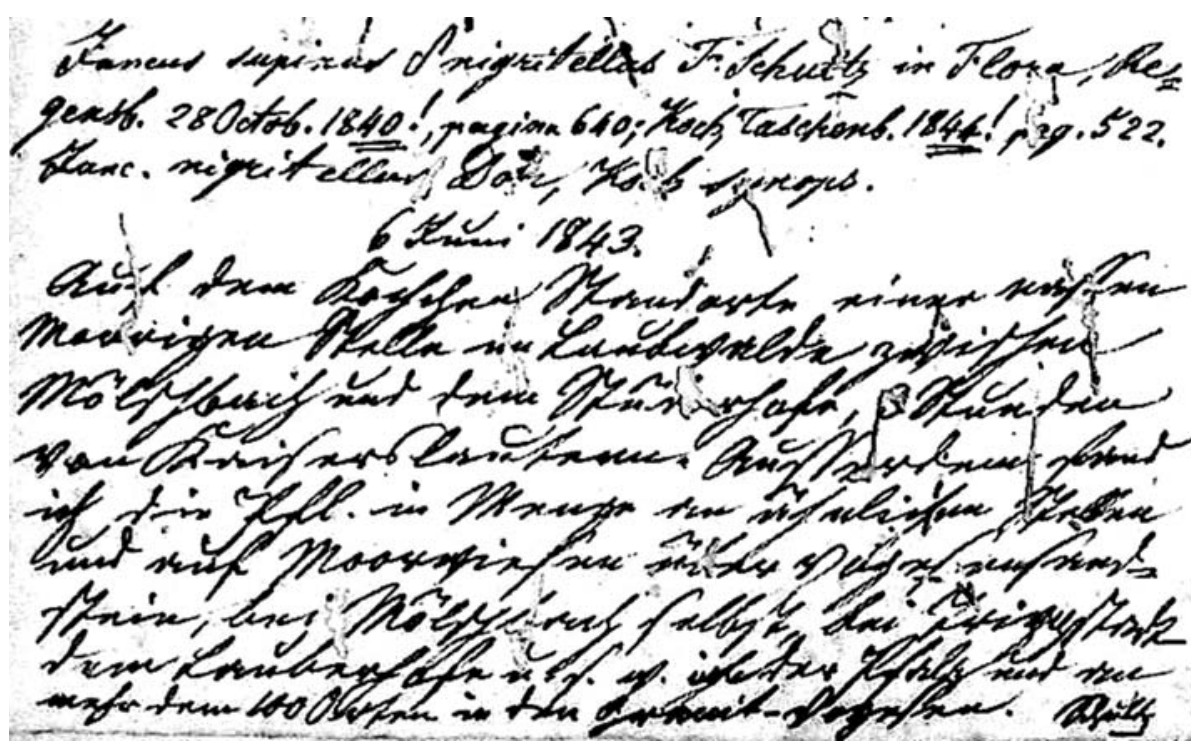

Fig. 2. Schultz's gothic handwriting label from the herbarium sheet RB 180551 partly damaged by pest insects (photo sent by Jardim Botânico do Rio de Janeiro, Herbário, Brasil).
Based on the detailed taxonomic analyses, Schultz's herbarium material from the environs of Bitche (Moselle, Lorraine) and Gérardmer (Vosges, Lorraine) - both in France (i.e., a major part of the material mentioned within points 2 and 3, above), was critically formerly discussed and has been rejected as useless for typification of J. kochii because of taxonomic reasons, though it was listed both in the protologue and also as indirect references therein Schultz's earlier publications (Proćków 2006b).

\section{THE ORIGINAL HERBARIUM MATERIAL EXAMINED}

with detailed localities and original determinations is as follows:

[Abbreviation: HK - "Herbarium viri doctiss. W. D. J. Koch [Prof. Erlang., $\uparrow 1849$ ] documentale et normale ad illius opus c. t. Synopsis Florae Germanicae et Helveticae. acq. W. F. R. Suringar 1865.“]

Germany (Rhineland-Palatinate):

A) Auf Ihrem Standorte beim Stüderhof von H.[errn] Böhmer gesammelt und mir mitgetheilt [Schultz's handwriting]. July 1838, HK, Böhmer/Schultz? [see comments below] (L 106429 ex Herb. W. D. J. Koch!) - Juncus nigritellus [7 plants] - Fig. 1 and 2 in Proćków 2007;

B) Sumpfige Waldwiese und Rand der Gräben und des kleinen Waldbächleins an der sogenannten Mooswiese bei Mölsch-

\section{Flora Gallice et Germaniae exsiccata. $-4^{\mathrm{e}}$ Cent.}

55. Juncus nigritellus, Don. Engl. bot. suppl. $t$. 2645; K. Syn. $\mathbf{7 5 0}$.

\section{Juillet 1828.}

Côte marécageuse dans les bois des montagnes, du grès vosgien, à Mœlschbach, près Kaiserslautern; déc. Kocb, rec. Bœhmer. Tantiari 1841 .

Fig. 3. Exsiccate printed label from the herbarium of J. Gay (K! - bottom left part of the sheet) with: (1) the proof that the specimen was certainly examined by F. W. Schultz, and (2) probably an erroneous year of collection - see Discussion (photo by the author). bach. 5 Sep 1843, HK, F. Schultz (L 106430 ex Herb. W. D. J. Koch!) - Juncus supinus $\delta$ nigritellus mihi [2 plants] Fig. 1A and B;

C) Auf dem Kochschen Standorte einer nassen moorigen Stelle im Laubwalde zwischen Mölschbach und dem Stüderhofe, 3 Stunden von Kaiserslautern. Ausserdem fand ich die Pfl.[anze] in Menge an ähnlichen Stellen und auf Moorwiesen über Vogesensandstein, bei Mölschbach selbst, bei Trippstadt dem Lauberhofe u. s. w. in der Pfalz und an mehr denn 100 Örten in den Granit-Vogesen. 6 June 1843, Schultz (RB 180551, photo seen) - Juncus supinus $\delta$ nigritellus $\mathrm{F}$. Schultz [6 plants] - Fig. 2;

D) Côte merécageuse dans les bois des montagnes, du grés vosgien, à Moelschbach, prés Kaiserslautern. 28 July 1828 [prob. 1838! - see comments below], Flora Galliae et Germaniae exsiccata $-4^{\mathrm{e}}$ Cent., Boehmer, No. 55, Schultz misit Jan 1841 (K ex Herb. J. Gay! - bottom left part of the sheet) - Juncus nigritellus Don, Engl. bot. suppl. t. 2643, K. Syn. 730 [2 plants] - Fig. 3;

E) Sumpfige Stellen sowohl im Walde als in Moorwiesen bei Mölschbach und Trippstadt gemein. [add. remark in red on the label:] Autographen F. Schulzii. 6 July 1843, F. Schultz (BM 792845 ex Herb. R. J. Shuttleworth!) - Juncus nigritellus Don [the name erased], Juncus supinus $\delta$ nigritellus F. Schultz, Juncus kochii F. Schultz [1 plant] - Fig. 4A and B;

F) [En fleurs] Endroit marécageux d'une côte dans les forêts sur le grès vosgien près de Moelschbach, aux environs de Kaiserslautern. [En fruits] Marais tourbeux sur le grès vosgien dans la vallée entre Trippstadt et le Johanniskreuz, aux environs de Kaiserslautern. 6 July 1843 [en fleurs], 5 Sep 1843 [en fruits], Flora Galliae et Germaniae exsiccata, Add. au n ${ }^{\circ} 56$ de la $4^{\mathrm{e}}$ cent., F. Schultz, No. 56 (M 10234!; HAL 86172!; B!; L ${ }^{\mathrm{I}} 106418$ !; L ${ }^{\mathrm{II}} 106426$ ex Herb. Hasskarl!; K ex Herb. J. Gay!; JE!; GI 13213 ex Herb. Delessert!; GII 13214 ex Herb. de Candolle!; PI 403941 ex Herb. Grenier! - Fig. 5; PII 494149 ex Herb. E. Cosson!; NCY ex Herb. Soyer-Villemet, photo seen) - Juncus supinus $\delta$ nigritellus F. Schultz in Flora, bot. Ztg. 1840, p. 640; J. nigritellus Don; K. Syn. 730 [M - 6 plants, $\mathrm{HAL}-6, \mathrm{~B}-7, \mathrm{~L}^{\mathrm{I}}-3, \mathrm{~L}^{\mathrm{II}}-3, \mathrm{~K}-7, \mathrm{JE}-4$, $\left.\mathrm{G}^{\mathrm{I}}-6, \mathrm{G}^{\mathrm{II}}-8, \mathrm{P}^{\mathrm{I}}-6, \mathrm{P}^{\mathrm{II}}-9, \mathrm{NCY}-4\right]$.

\section{DISCUSSION}

In the case of $J$. kochii it is important that Schultz (1855) provided its new diagnosis (not cited directly from earlier 


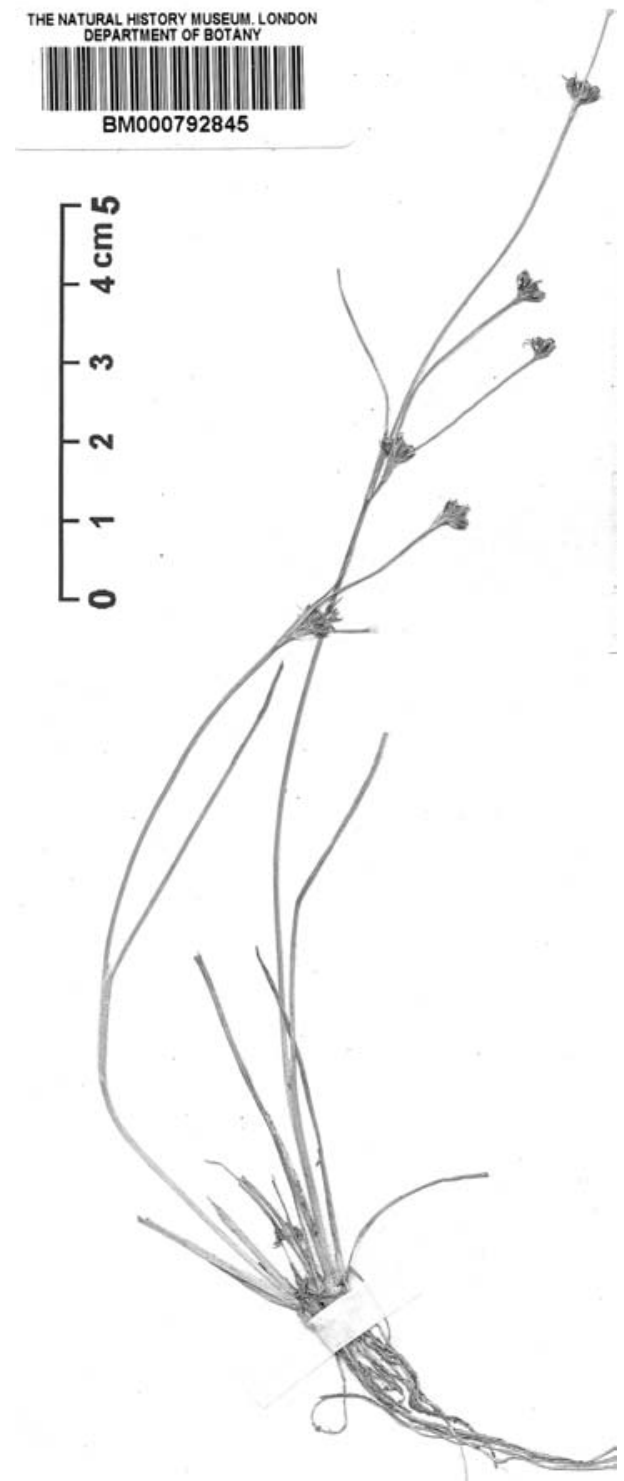

Fig. 4A. Original material of Juncus kochii collected by F. W. Schultz between Mölschbach and Trippstadt (Germany) in 1843 - the plant from the herbarium sheet BM 792845 ex Herb. R. J. Shuttleworth! (photo by the author).

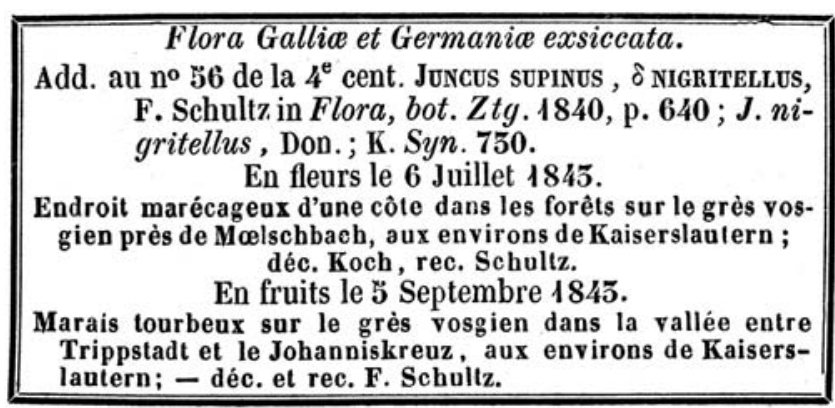

Fig. 5. Isosyntype printed label from the herbarium of J. Ch. M. Grenier (P 403941!) where it is stated that the exsiccate sheet contains a mixed material from two localities and besides collected by F. W. Schultz on different dates, with no possibility to assign precise localities to particular plants - see Discussion (photo by the author).

('Peren.') and the habitat ('gewöhnlich zwischen faulem Laube, faulem Nadeln, Sphagnum oder Hypnum'), as well as the fact that additional localities were listed, mean that it is not a nomen novum for Juncus supinus var. nigritellus W. D. J. Koch, nom. illeg. with which it was therefore not necessarily homotypic! Thus the name Juncus kochii was validly published, the species was clearly described, and the original material was specified by the author. But as recently lectotypification was made (Proćków 2006a) both names (J. kochii F. W. Schultz and J. supinus var. nigritellus W. D. J. Koch) just now are homotypic indeed.

Therefore there are 17 herbarium specimens, i.e., 6 specimens and 11 duplicates (not 16 as stated in Proćków (2006a), because the additional duplicate of Schultz's exsiccate No. 56, Add. - P 494149 ex Herb. E. Cosson has been found). They appear to represent original material and the most of them fit well with Schultz's description and reflect well his concept of $J$. kochii and the current application of the epithet, except for F. Schultz, No. 56, Add. from JE, where both top plants and the bottom left plant have green perianths and the same situation is for $F$. Schultz, No. 56, Add. from K (ex Herb. J. Gay), where the top second plant from the left has green perianths as well (see also remarks on G 13214-sheet, below). Namely, in

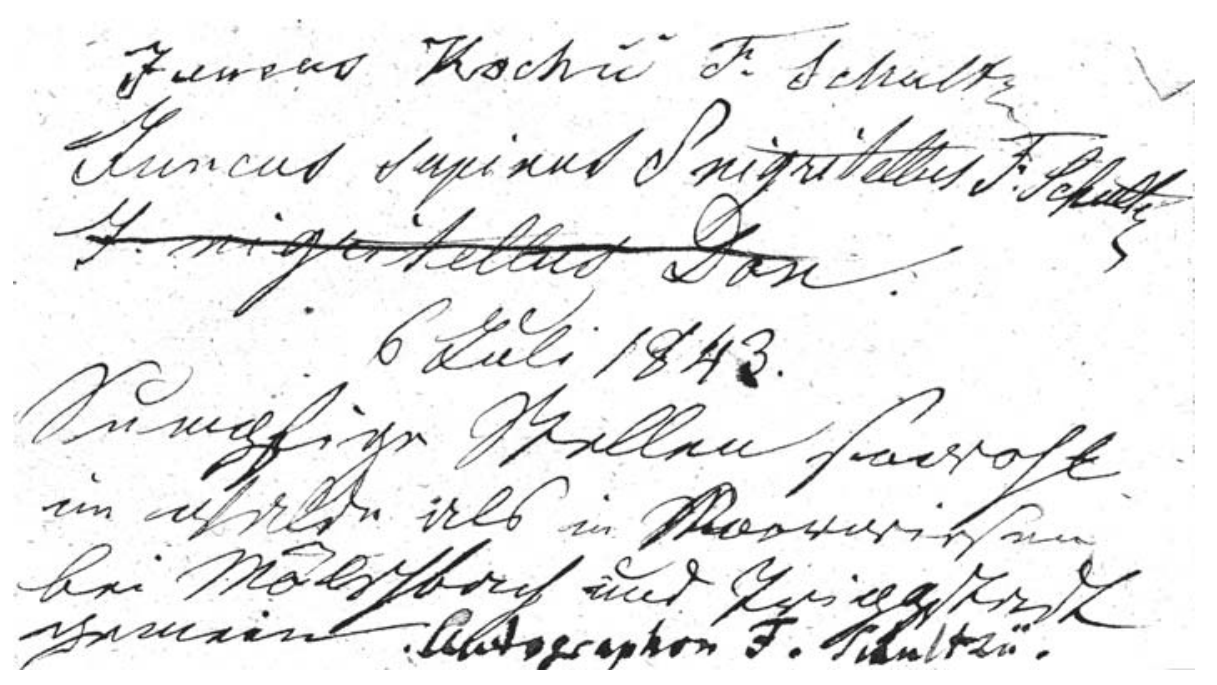

Fig. 4B. Schultz's gothic handwriting label from the herbarium sheet which was subsequently acquired by R. J. Shuttleworth, with: (1) the additional remark (in red) on the label: "Autographen F. Schulzii", and (2) the erased name "Juncus nigritellus Don" as incorrect - see Introduction (BM 792845! photo by the author). works - see Introduction). Its existence (as a narrowed and slightly modified set of characters), combined with additional information on the flowering time (besides July, additionally June was mentioned), durability of the life form the protologue Schultz (1855) states that flowers of rushes are usually lighter when the plants grow in cooler or shaded places. Schultz was, however, convinced that such habitat conditions had no effect on the perianth colour in $J$. 
kochii (it should be always 'dark, usually black-red or violet-brown'). But my recent taxonomic revision of the diagnostic features of $J$. bulbosus subsp. kochii showed that the taxon also can have greenish or green perianth segments (Proćków 2008a). The information from herbarium labels, on the location of the localities and the habitat of the examined specimens was not in disagreement with the protologue as well. Comparative characters, based on the protologue of Juncus kochii, between J. bulbosus subsp. kochii and subsp. bulbosus in the floral and fruit characters are shown in the Table 1 in Proćków (2006a).

Specimen and his duplicates from 'Fl. Gall. \& Germ. Exsicc., Add. au n $\mathrm{n}^{\circ} 56$ de la $4^{\mathrm{e}}$ cent.' (listed as F, above) contain a mixed material from two localities i.e. neighbourhood of Mölschbach and Trippstadt and Johanniskreuz (besides, collected on different dates), with no possibility to assign precise localities to particular plants (Fig. 5). However, almost the whole collection is in agreement with the protologue except the top middle and top right plants of G 13214, with characters that disagree with the diagnosis the specimens do not represent subsp. kochii (and it should as well be noted that such information was not stated in Proćków 2006a, wherein J. kochii was recently lectotypified). In the situation it is also important that the discussed specimens of the collection have to be regarded as isosyntypes because they are really cited as specimens (not locality data) in the indirect reference in 'Fl. d. Pfalz' [Schultz 1846], i.e. as 'Fl. G. et G. exs., add. au 56 de la $4^{\mathrm{e}}$ Cent.' (see point 3 , above). In turn, the herbarium specimens of residual original material of $J$. kochii (listed as B-E, see above) are not syntypes because in fact they are not cited in the protologue as specimens, only locality data (cf. McNeill et al. 2006: Art. 9.4). However, in my opinion in the particular case, the whole original material (listed as B-F, i.e., both the specimens are isosyntypes or not) have equal rights to be selected as lectotype of $J$. kochii in a subsequent lectotypification, if actual recently designated type would have been lost or destroyed in the future (but compare McNeill et al. 2006: Art. 9.10). Namely the residual original material (listed as B-E) is not mixed (plants are collected in one given locality) while isosyntypes are (see above).

The specimen, Fl. Gall. \& Germ. Exsicc. No. 55 from K (bottom left part of the sheet), though collected by Böhmer (see also below), can be regarded as original material, since it was certainly examined by Schultz (note on the label: 'Schultz misit Jan 1841' - Fig. 3). The sheet probably contains also an erroneous year of collection (though not necessarily, since the plants for the exsiccate could have been collected much earlier): 1838 seems more likely than 1828 , as suggested by: (1) No. 56 of 4th Cent. of the Fl. Gall. \& Germ. Exsicc. (plants from this sheet were collected on 28 Jun 1839) and (2) the reference 'K. Syn. 730' [Koch, Syn. Fl. Germ. Helv. 730 (1837)] on the herbarium label (Fig. 3).

In turn, lectotype of $J$. kochii (and of J. supinus var. nigritellus accordingly) is the specimen L 106429 (see Figures 1 and 2 in Proćków 2007). Schultz obtained the plants from the sheet also from Böhmer (he did not collect them himself - see above), but an additional, narrow, probably later added label bears information 'supinus nigritellus Schultz legit' (see Figure 2 in Proćków 2007).
Furthermore, the names $J$. kochii and $J$. welwitschii Hochst. ex Steud. are often treated as synonymous (e.g., by Lindberg 1933 or Rothmaler \& all. 1986, who both most likely had never seen any type material of the taxa). But only one sheet/plant of the whole original material of $J$. welwitschii (G 12606 ex Hb. Delessert) really belongs to $J$. bulbosus subsp. kochii (Proćków 2006c). So J. welwitschii should be excluded from the synonymy of J. kochii what may be summarized thus:

Juncus bulbosus L. subsp. kochii (F. W. Schultz) Reichg. in S. J. van Ooststroom \& al., Fl. Neerl. 1 (6): 189. 1964. 三Juncus kochii F. W. Schultz, Jahresber. Pollichia 13: 32. 1855. $\equiv$ Juncus supinus Moench var. kochii (F. W. Schultz) Syme, Engl. Bot., ed. 3B (10): 33. 1870. इJuncus supinus subsp. kochii (F. W. Schultz) Nyman, Consp. Fl. Eur. 748. 1882. $\equiv$ Juncus supinus race kochii Rouy, Fl. France 13: 244. 1912. 三Juncus supinus var. nigritellus W. D. J. Koch, Syn. Fl. Germ. Helv., ed. 2 (2): 843. 1844, nom. illeg. (non (D. Don) F. W. Schultz, 1840).

LECTOTYPE (designated by J. Proćków, 2006a: 790): [Rhineland-Palatinate, SW Germany] “Auf Ihrem Standorte beim Stüderhof von H.[errn] Böhmer gesammelt und mir mitgetheilt" [Schultz's handwriting]. Jul 1838, "Juncus nigritellus”, Böhmer/F. W. Schultz? - L 106429 ex Herb. W. D. J. Koch! (Figs 1 and 2 in Proćków 2007).

Isosyntypes: M 10234!; HAL 86172!; B (Schultz 56, Add.)!; L 106418!; L 106426 ex Herb. Hasskarl!; K ex Herb. J. Gay (Schultz 56, Add.)!; JE (Schultz 56, Add.)!; G 13213 ex Herb. Delessert!; G 13214 ex Herb. de Candolle (except the top middle and top right plants)!; P 403941 ex Herb. Grenier! (Fig. 5); P 494149 ex Herb. E. Cosson!; NCY ex Herb. Soyer-Villemet (Schultz 56, Add.), photo seen [i.e. duplicates listed as F, above].

Residual original material of J. kochii: L 106430 ex Herb. W. D. J. Koch! (Fig. 1A and B); RB 180551, photo seen (Fig. 2); K ex Herb. J. Gay (Boehmer 55)! - bottom left part of the sheet (Fig. 3); BM 792845 ex Herb. R. J. Shuttleworth! (Fig. 4A and B) [i.e. specimens listed as BE, above].

SYNONYM EXCLUDED HERE: Juncus welwitschii Hochst. ex Steud., Syn. Pl. Glumac. 2: 304. 1855. इJuncus supinus Moench var. welwitschii (Hochst. ex Steud.) Cout., Bol. Soc. Brot. 8: 106. 1890. $\equiv$ Juncus supinus subsp. welwitschii (Hochst. ex Steud.) K. Richt. Pl. Eur. 1: 180. 1890. $\equiv$ Juncus bulbosus L. f. welwitschii (Hochst. ex Steud.) Soó, Acta Bot. Acad. Sci. Hung. 16 (3-4): 366. 1971. HOLOTYPE: Portugal. "In arena humida ad ripam Tagi sinistram. June 1840" F. M. J. Welwitsch 324 (P!). Isotypes: TUB 11144!, K!, FI 185300, photo seen. Isosyntype: SW Portugal, prov. Setúbal. "In Extremadurae transtagarae humidis arenosis intra Coina \& Azeitão rarius. 20 June 1840" F. M. J. Welwitsch 324 (LISU-P7749!; Fig. 1 in Proćków 2006c). Isotype or isosyntype: $\mathrm{W}$, not seen.

\section{ACKNOWLEDGEMENTS}

I am grateful to the herbarium curators who searched through their collections on my behalf or who sent original material for this research: AAU, B, BM, BP, BR, BUC, C, DAO, E, ER, FI, G, GB, GDOR, GH, GOET, HAL, JE, K, KSC, L, LISU, LIV, LZ, M, NCY, NMW, OUPR, OXF, P, 
POLL, RB, S, TUB, VT, W, WAG, WB, WRSL. I would like to thank Doc. Dr Jan Kirschner (Institute of Botany, Academy of Sciences of the Czech Republic, Průhonice) for his time and his valuable help and comments. Special thanks go also to the Nomenclature Editor of Taxon, Prof. John McNeill for his valuable remarks. This research - the visits to the collections and libraries of Muséum National d'Histoire Naturelle, Paris (FR-TAF), Natural History Museum, London, Royal Botanic Gardens Kew, Richmond \& Royal Botanic Garden Edinburgh (GB-TAF) - received support from the SYNTHESYS Project http: //www.synthesys.info/ which is financed by European Community Research Infrastructure Action under the FP6 "Structuring the European research Area" Programme led by the European Commission. I am grateful to Dr Peter Stafford, Dr Mark Spencer and Christopher J. S. Davis (BM), Dr David Harris, Dr Douglas McKean and Helen Hoy (E), Dr Dave Simpson and Martin Xanthos (K), Prof. Gérard G. Aymonin, Dr Marc Pignal and Cécile Aupic (P) for their help during my study at BM, E, K and P. I thank Prof. Wojciech Kunicki (Head of the Department of German Literature Till 1848, Wrocław University) for deciphering herbarium labels - Schultz's gothic handwriting in German (listed as A-C and E), Prof. Jacques Lambinon (LG) and Dr Gaëtan Guignard (LY) for their help when deciphering abbreviations on French herbarium labels and Dr Stefan Dressler (FR) for information which proved useful when searching for Schultz's Herbarium. I also thank the head of my department, Prof. dr hab. Jadwiga Anioł-Kwiatkowska, for her support and encouragement.

\section{LITERATURE CITED}

CASPER S.J., KRAUSCH H.-D. 1980. Pteridophyta und Anthophyta. Lycopodiaceae bis Orchidaceae. In: Süßwasserflora von Mitteleuropa. Pascher A. (ed.). VEB Gustav Fischer Verlag, Jena, Vol. 23 (1), pp. 1-403.

GREUTER W., McNEILL J., BARRIE F.R., BURDET H.-M., DEMOULIN V., FILGUEIRAS T.S., NICOLSON D.H., SILVA P.C., SKOG J.E., TREHANE P., TURLAND N.J., HAWKSWORTH D.L. (eds). 2000. International Code of Botanical Nomenclature (Saint Louis Code) adopted by the Sixteenth International Botanical Congress, St. Louis, Missouri, July-August 1999. Regnum Vegetabile 138. Koeltz, Scientific Books, Königstein.

KIRSCHNER J. (ed.). 2002. Juncaceae 2: Juncus subg. Juncus, Species Plantarum: Flora of the World 7: 1-336. Australian Biological Resources Study, Canberra.

KOCH G.D.J. 1837. Synopsis florae germanicae et helveticae, exhibens stirpes phanerogamas rite cognitas, quae Germania, Helvetia, Borussia et Istria sponte crescunt atque in hominum usum copiosius coluntur. Secundum Systema Candolleanum digestas, praemissa generum dispositione, secundum classes et ordines systematis Linnaeani conscripta. Sectio prior. Ed. 1 (2). Sumptibus Friederici Wilmans, Francofurti ad Moenum.

KOCH G.D.J. 1844. Synopsis florae germanicae et helveticae, exhibens stirpes phanerogamas et vasculares cryptogamas rite cognitas, quae Germania, Helvetia, Borussia et Istria sponte crescunt atque in hominum usum copiosius coluntur. Secundum Systema Candolleanum digestas, praemissa generum dispositione, secundum classes et ordines systematis Linnaeani conscripta. Ed. 2 (2). Sumptibus Gebhardt et Reisland, Lipsiae.

LINDBERG H. 1933. Juncus welwitschii Hochst. (J. Kochii F. Schultz), en misskänd västlig art. Memor. Soc. pro Fauna et Flora Fenn. 9: 156-160.

McNEILL J., BARRIE F.R., BURDET H.M., DEMOULIN V., HAWKSWORTH D.L., MARHOLD K., NICOLSON D.H., PRADO J., SILVA P.C., SKOG J.E., WIERSEMA J.H., TURLAND N.J. (eds). 2006. International Code of Botanical Nomenclature (Vienna Code) adopted by the Seventeenth International Botanical Congress, Vienna, Austria, July 2005. Regnum Vegetabile 146. A.R.G. Gantner Verlag KG, Ruggell.

PROĆKÓW J. 2002. A more precise lectotypification of Juncus bulbosus L. (Juncaceae). Taxon 51 (3): 551-552.

PROĆKÓW J. 2006a. Lectotypification of Juncus kochii and Juncus supinus var. nigritellus (Juncaceae). Taxon 55 (3): 788-790.

PROĆKÓW J. 2006b. Rejection of some original material of Juncus kochii (Juncaceae) as useless for typification. Acta Soc. Bot. Pol. 75 (4): 297-300.

PROĆKÓW J. 2006c. Nomenclatural notes on Juncus welwitschii (Juncaceae). Ann. Bot. Fenn. 43 (4): 307-309.

PROĆKÓW J. 2007. Nomenclatural notes on Juncus supinus var. nigritellus - a new synonym of Juncus bulbosus L. subsp. kochii (Juncaceae). Ann. Bot. Fenn. 44 (1): 68-71.

PROĆKÓW J. 2008a. What is Juncus bulbosus subsp. kochii (Juncaceae) and does it really exist? A taxonomic revision of bulbous rush subspecies. Bot. J. Linn. Soc. 156 (4): 501-512.

PROĆKÓW J. 2008b. Juncus bulbosus (Juncaceae), a species new to South America (Chile). Acta Soc. Bot. Pol. 77 (3): 225-227.

ROTHMALER W., SCHUBERT R., VENT W. 1986. Exkursionsflora für die Gebiete der DDR und der BRD. Band 4. Kritischer Band. Volk und Wissen Volkseigener Verlag, Berlin.

SCHULTZ F.W. 1846. Flora der Pfalz: enthaltend ein Verzeichnis aller bis jetzt in der bayerischen Pfalz und den angränzenden Gegenden Badens, Hessens, Oldenburgs, Rheinpreussens und Frankreichs beobachteten Gefäßpflanzen, mit Angaben der Dauer und der Blüthezeit, aller bis jetzt bekannt gewordenen Fundorte und Finder, der Natur der Fundorte und der geognostischen Beschaffenheit des Bodens, mit Merkmalen neuer und zweifelhafter Arten und anderen Bemerkungen, nach Kochs Synopsis und Taschenbuch der deutschen und Schweizer Flora geordnet, und nebst Beifügung der Anordnung der Gattungen nach dem Linneischen Sexualsysteme, der tabellarischen Uebersicht der Ordnungen des natürlichen Systems, sowie der Gattungs- und Artenmerkmale, im Auszuge aus diesen Werken. G. L. Lang, Speyer.

SCHULTZ F.W. 1855. Standorte und Verbreitung der Juncaceen und Cyperaceen in der Pfalz. Jahresbericht der Pollichia, eines naturwissenschaftlichen Vereins der Rheinpfalz 13: 30-54. 